\title{
SAFETY MODIFICATIONS TO MOBILE HYPOTHERMIA UNTS
}

\author{
Douglas B. Craig and Barry A. Pask
}

THE ANAESTHETIST occasionally finds himself the operator of mobile thermal units which circulate either heated or cooled liquids through special "blankets" in contact with the patient. Although used by anaesthetists, these devices are not normally considered anaesthetic equipment. The current comprehensive anaesthetic textbooks, as well as several monographs on anaesthetic equipment include minimal, if any, reference to the design and safe operation of mobile thermal units. Even Blair's classic monograph on clinical hypothermia ${ }^{1}$ and a recent textbook on accidental hypothermia ${ }^{2}$ do not, in their sections on specific techniques, provide guidelines for the safe use of thermal units, either for heating or cooling.

In spite of this lack of emphasis on the safe use of mobile thermal units there is clear evidence that serious patient injury can be associated with their use, either in the presence $e^{3-6}$ or absence ${ }^{7.8}$ of equipment malfunction.

The purposes of this communication are three-fold. First we remind anaesthetists, as occasional users of mobile thermal units, of the possibility of equipment malfunction, leading to patient injury. Second, as an example of specific safety problems, we compare and contrast the safety features of two thermal units, one old and one new. Third, we provide specific guidelines for the addition of safety devices to the older units, with the aim of making these units equivalent in safety features to contemporary models. The specific mobile thermal units discussed are intended for illustration purposes only, and can be viewed as representative of other similar units of different origins. Direct comparisons of various models of mobile thermal units have been published. ${ }^{9,10}$

The Table summarizes the thermal safety features of an unmodified older unit (RK 101), a new unit (RK 600) and a modified older unit (RK 101).

Douglas B. Craig. M.D., F.R.C.P.(C). Department of Anaesthesia. University of Manitoba; Barry A. Pask, P. Eng.. Biomedical Engineering Departmenı, Health Sciences Centre, Winnipeg.

Reprint requests: Dr. Douglas B. Craig, Department of Anaesthesia. University of Manitoba. Health Sciences Centre-General. 700 William Ave.. Winnipeg. Manitoba, R3E 0Z3.
It is clear that the unmodified older unit had the potential to produce uncontrolled and dangerously high temperatures. We found one such unit capable of heating the circulating liquid to $64^{\circ} \mathrm{C}$ Details of our modification, which is illustrated in the Figure, follows.

We have added two high temperature thermostats which set limits to the heat output of the unit by shutting off power to the unit when these limits are exceeded. Limitation of the low temperature output is assured by a single thermostat. Visual and audible warnings of abnormal high or low temperatures are also provided. Mechanical modification of the temperature control knob limits its excursion beyond the normal safe operating range. Finally, a test facility is provided for the temperature protection circuit.

The safety circuit uses mercury-in-glass thermostats, because of their small size $\left(0.140^{*}\right.$ dia. $x$ $1 t^{\prime \prime}$ long) and excellent tolerance $\left( \pm 0.5^{\circ} \mathrm{C}\right.$ or better). Two solid-state power relays and two high limit thermostats are used for redundant safety. Any other circuit failures (including shorts to ground) are fail-safe. The "TEST" switch. mounted on the front panel, provides a quick test of the whole circuit except for the high limits. which can only be checked by over-riding the temperature control to cause overheating (this is done twice a year).

The safety circuit is powered as soon as the unit is plugged in. Rectified current is supplied to the control sections of both relays, which causes the power contacts of the relays to close at every zero-crossing of the A-C voltage across them. The $10 \mathrm{~K}, 2 \mathrm{~W}$ resistors allow the relays to properly sense zero voltage, so that turn-on does not occur at non-zero voltages when the resulting current surge could destroy the relays. Should the rectified current for any reason be prevented from flowing through the control section of either relay, the contacts of that relay will remain open, shutting off the power to the rest of the unit and creating 110 VAC to drive the Sonalert and the "TEMP ALARM" lamp. The thermostats and the "TEST" switch are simply methods of preventing current from reaching the relay control sections when this is desired. Turning off the power switch of the unit opens the current path for the alarms 
TABLE I

\begin{tabular}{|c|c|c|c|}
\hline Feature & $\begin{array}{l}\text { GR* model RK-600 } \\
\text { purchased } 1978\end{array}$ & $\begin{array}{l}\text { GR* model RK=101 } \\
\text { purchased } 1963\end{array}$ & $\begin{array}{l}\text { GR* model RK-101 } \\
\text { modified } 1978\end{array}$ \\
\hline $\begin{array}{l}\text { Limitation to } \\
\text { manual setting } \\
\text { of hazardous } \\
\text { temperature }\end{array}$ & $\begin{array}{l}\text { Mechanical- } \\
\text { limited by } \\
\text { switch positions }\end{array}$ & $\begin{array}{l}\text { Mechanical- } \\
\text { Pin in knob } \\
\text { passes through } \\
\text { hole in panel } \\
\text { (not visible) }\end{array}$ & $\begin{array}{l}\text { Visible } \\
\text { mechanical } \\
\text { stop added }\end{array}$ \\
\hline $\begin{array}{l}\text { Limitation to } \\
\text { high temperature } \\
\text { output }\end{array}$ & $\begin{array}{l}\text { Two thermostats: } \\
\text { both at } \\
44^{\circ} \mathrm{C}\end{array}$ & None & $\begin{array}{l}\text { Primary thermostat } \\
42^{\circ} \mathrm{C} \\
\text { Secondary thermostat } \\
46^{\circ} \mathrm{C}\end{array}$ \\
\hline $\begin{array}{l}\text { First safety } \\
\text { thermostat }\end{array}$ & $63^{\circ} \mathrm{C}$ & $65^{\circ} \mathrm{C}$ & $65^{\circ} \mathrm{C}$ \\
\hline $\begin{array}{l}\text { Limitation to } \\
\text { low temperature } \\
\text { output }\end{array}$ & $\begin{array}{l}\text { Thermostat } \\
+2^{\circ} \mathrm{C}\end{array}$ & None & $\begin{array}{l}\text { Thermostat } \\
+2^{\circ} \mathrm{C}\end{array}$ \\
\hline $\begin{array}{l}\text { Visual warning } \\
\text { of abnormal high } \\
\text { temperature }\end{array}$ & Red light & None & Red light \\
\hline $\begin{array}{l}\text { Visual warning } \\
\text { of abnormal low } \\
\text { temperature }\end{array}$ & Red light & None & Red light \\
\hline $\begin{array}{l}\text { Audible alarm } \\
\text { if abnormal } \\
\text { temperature }\end{array}$ & No & No & Yes \\
\hline $\begin{array}{l}\text { Test facility } \\
\text { for temperature } \\
\text { protection circuit }\end{array}$ & No & No & Yes \\
\hline
\end{tabular}

*Gorman-Rupp.

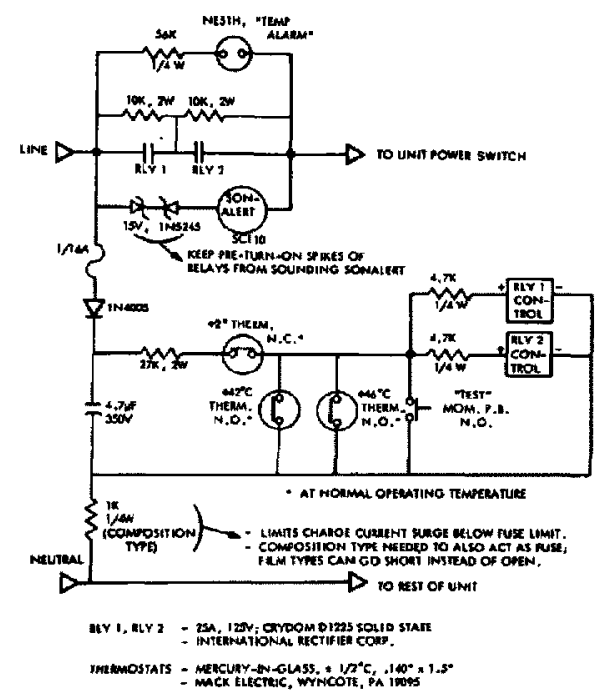

Figure 1 Schematic diagram of high and low temperature safety circuits and alarms for mobile hypothermia machine. See text for description. and shuts them off, but does not disable the safety shut-off circuit itself.

Circuit construction was done on a $2^{\prime \prime} \times 3^{\prime \prime}$ piece of Vero (T.M.) board. The thermostats were mounted with their mercury ends inside copper wells made from $t^{\prime \prime}$ I.D. copper tubing drilled out to $0.140 \mathrm{inch}$. To reduce false alarms during operation at $40^{\circ} \mathrm{C}$ due to the safety thermostats being faster-acting than the control thermostats, the copper wells were soldered to the piping after the control thermostat. The pipe was wrapped with one or two layers of electrician's tape for electrical insulation, the thermostats were inserted, and more tape was then wrapped over everything. The visible mechanical stop involved replacing the old round knob with a pointer knob and pop-rivetting 3 small washers in a stack to the front panel, so that the pointer came up against them when pointing to $40^{\circ} \mathrm{C}$.

The time required to modify one unit was 8 to 10 hours and the cost of parts about $\$ 100$. The unit should, of course, also be inspected for proper operation, calibration, and electrical safety 
after the modification is completed, and any faults must be corrected. This same modification has also been successfully fitted to Gorman-Rupp Model RK 200 units.

The total cost of the modification described is about one-tenth of the purchase price of a new unit. However, modification would offer an acceptable alternative to replacement of equipment only in centres where qualified biomedical engineering technologists are available to undertake such modifications and to administer on-going programs to confirm continuing safe operation of the units. Otherwise the modifications described should not be attempted.

Operators of mobile thermal units should be aware of the major safety deficiencies of some older models, and should insist on either modification where appropriate, or replacement.

\section{SUMMARY}

Major safety deficiencies of older mobile hypothermia units are described. Problems include absence of high or low temperature output limitation or of visual warning of abnormal operating temperatures. Modifications described provide two high temperature thermostats and one low temperature thermostat, which shut the unit down if the temperature limits are exceeded. Visual and auditory alarms were also added Operators of mobile thermal units should be aware of the major safety deficiencies of some older models, and should insist on either modification, where appropriate, or replacement.

\section{RÉSUMÉ}

Les auteurs décrivent les faiblesses inhérentes aux anciens modèles d'appareils d'hypothermie qui sont labsence de mécanisme limitant les hautes et les basses températures et l'inexistence de moniteurs visuels de températures excessives. Les modifications apportées consistent en l'addition de thermostats de haute et de basse température qui coupent le fonctionnement de J'appareil lorsque Jes limites sont dépassées. Des alarmes visuelles et auditives ont aussi été ajoutées. Les usagers de ces appareils doivent ėtre conscients des déficiences présentes sur les anciens modèles et doivent insister pour les faire remplacer ou au moins pour les faire modifier.

\section{REFERENCES}

1. BLAIR, E. Clinical hypothermia. I st ed. New York: McGraw-Hial (1964)

2. Maclean, D. \& Emslie-Smith, D. Accidental hypothermia, Ist ed. Oxford: Blackwell (1977).

3. Thermal safety of hyper-hypothermia machines. Medical Devices Alert No. 8. Health Protection Branch, Health and Welfare Canada. April 3, 1978.

4. Hazard: Gaymar hypothermia machine. Health devices. 3: 229-230 (1974).

5. Hazard: Gorman-Rupp hypothermia machine. Health devices 3: 231 (1974)

6. Hazard: Gorman-Rupp hypothermia machine. Health devices 3: 232-233 (1974).

7. Scorr, S.M. Thermal blanket injury in the operating room. Arch. Surg. 94: 181 (1967).

8. CRINO M.H \& NAGEL E.L. Thermal burns caused by warming blankets in the operating room. Anesthesiology 29: 149-150 (1968).

9. Mobile hypothermia machines. Evaluation. Health devices 2: 79-82 (1973).

10. Mobile hypothermia machines. Evaluation. Health devices $I: 52-70$ (1971). 